\title{
Integrated health service delivery networks and tuberculosis avoidable hospitalizations: is there a relation between them in Brazil? \\ CrossMark
}

Marcela Paschoal Popolin ${ }^{*}$, Michelle Mosna Touso', Mellina Yamamura', Ludmila Barbosa Bandeira Rodrigues², Maria Concebida da Cunha Garcia', Luiz Henrique Arroyo ${ }^{1}$, Antônio Carlos Vieira Ramos ${ }^{1}$, Thais Zamboni Berra', Marcelino Santos Neto ${ }^{3}$, Juliane de Almeida Crispim', Francisco Chiaravalotti Neto ${ }^{4}$, Ione Carvalho Pinto ${ }^{1}$

Pedro Fredemir Palha', Severina Alice da Costa Uchoa ${ }^{5}$, Luís Velez Lapão ${ }^{6}$, Inês Fronteira ${ }^{7}$

and Ricardo Alexandre Arcêncio ${ }^{1}$

\begin{abstract}
Background: The early identification of the Breathing Symptoms within the scope of Primary Health Care is recommended, and is also one of the strategies of national sanitary authorities for reaching the elimination of tuberculosis. The purpose of this study is to consider which attributes and which territories have shown the most significant progress in Primary Health Care, in terms of coordination of Health Care Networks, and also check if those areas of Primary Health Care that are most critical regarding coordination, there were more or less cases of avoidable hospitalizations for tuberculosis.

Methods: This is an ecological study that uses primary and secondary data. For analysis, coropletic maps were developed through the ArcGIS software, version 10.2. There was also the calculation of gross annual and Bayesian rates for hospitalizations for tuberculosis, for each Primary Health Care territory.

Results: There were satisfactory results for attributes such as Population $(n=37 ; 80.4 \%)$, Primary Health Care $(n=43$; $93.5 \%)$, Support System ( $n=45 ; 97.8 \%)$; the exceptions were Logistics System ( $n=32 ; 76.0 \%)$ and Governance System, with fewer units in good condition $(n=31 ; 67.3 \%)$. There is no evidence of any connection between networks' coordination by Primary Health Care and tuberculosis avoidable admissions.

Conclusion: The results show that progress has been made regarding the coordination of the Health Care Networks, and a positive trend has been shown, even though the levels are not excellent. It was found no relationship between the critical areas of Primary Health Care and tuberculosis avoidable hospitalizations, possibly because other variables necessary to comprehend the phenomena.
\end{abstract}

Keywords: Primary Health Care, Health Care Network coordination, Tuberculosis, Hospitalization, Spatial analysis

\section{Background}

The year of 2015 starts with an audacious goal set by the World Health Organization (WHO), to eliminate tuberculosis (TB) completely by the year 2050 [1]. In 2013 alone, the world saw over 9 million cases of the disease identified, and within this universe only 6 million had

\footnotetext{
* Correspondence: marcelappopolin@gmail.com

${ }^{1}$ Maternal-Infant and Public Health Nursing Department, College of Nursing of Ribeirão Preto, University of São Paulo, Av dos Bandeirantes 3900,

14040-902 Ribeirão Preto, São Paulo, Brazil

Full list of author information is available at the end of the article
}

the possibility to access health services. Brazil is on the list of 22 countries that account for $80 \%$ of all TB cases in the world, being in $22^{\text {nd }}$ position when it comes to incidence with 46 cases per 100,000 inhabitants, and a prevalence of 57 cases per 100,000 inhabitants [1].

Also in this group, Brazil is one of the countries with the lowest percentage of patients completing their treatment (72\%), well below the targets defined by the WHO, of $85 \%$ [1], which puts the country in a situation of risk, especially because of multidrug resistance to tuberculosis (MDR-TB), which is when the patient 
becomes resistant to Rifampicin and Isoniazid. Among the expectations for the period after 2015, one is that the country could make progress in terms of the reorganization of its systems for ensuring access to the populations affected by the disease, especially the vulnerable segments.

Early identification of the Breathing Symptoms within the scope of Primary Health Care (PHC) is recommended, and is also one of the strategies used by national sanitary authorities to reach the expected target, which is the elimination of TB [2]. Counting on PHC for the coordination of care for the TB patient could have a significant effect in terms of completion of the course of treatment, and also in the breakage of the transmission chain, thanks to the reinforcement of the actions for promotion of health, prevention, treatment and rehabilitation, among others.

However, recent studies have shown an increase in admittances to hospital with TB [3, 4]; a transversal cut study in the municipality of São Paulo, comparing the outcomes between patients hospitalized with those receiving outpatient treatment, showed a lower rate of cure and a higher rate of mortality among the patients who had been hospitalized [5]. Another study, this one of an ecological type, performed in the state of São Paulo [6] showed a prevalence of hospitalizations among males, and also the presence of a significant number of hospitalized children, and clearly shows that PHC has been quite feeble in promoting health, prevention of new cases, diagnosis and early treatment.

There is a movement around the world towards the strengthening of the health system through PHC, with acknowledgement of its strategic function, so important for the organization of an integrated system, or a system in Networks [7]. The Pan-American Health Organization (PAHO) $[8,9]$ has recommended that Latin American and Caribbean countries organize their health systems using the logic of the Health Care Networks (HCNs), coordinated by the $\mathrm{PHC}$, understanding that the way in which they are currently organized has not contributed to a solution of the main health problems, while also producing sanitary indicators that are a cause for concern and hospitalizations that could be avoided, at very high costs which cannot be borne by countries of low to medium income.

Even though there is not one single organizational model for the HCNs coordinated by the PHC, evidence $[9,10]$ shows that a set of attributes is essential for the operation thereof, namely: Population and territories that are well defined, and in which there should be a significant knowledge of preferences and needs, which ends up being a determining factor in the supply of health services; Primary Health Care, which is a model for health care comprising a multiprofessional team which covers the whole population, being an entry point while integrating and coordinating health care; a Support System, which consists of systems for diagnostic and therapeutic support, information systems, and systems for tele-assistance; a Logistic System which is provided by the institution of electronic registration, access and regulation systems, and also the transport systems; and a Governance System which has been created for the whole Network, in order to establish and implement unique mission, vision and strategies for the health services that are part of this system.

We feel that a health event is avoidable when a system has all the resources or technologies available in the health area to solve the problems or even to make sure these do not occur; however, as a result of faults in the distribution system, allocation of resources, organization and supply of health actions, they end up occurring [11]. In this way, the PHC also has the social role of equalizing the offer of actions resulting from health demands of the population and under this logic, the systems raise their capacity to solve the problems and hence become more efficient and equitative [12].

In Latin America, reorganization centred on the coordination of care by PHC is still in its early stages. The history of segmentation and fragmentation of most of the Latin American systems, with an offer of selective $\mathrm{PHC}$, have weakened such aspects as the establishment of integrated networks and the continuation of health care [13]. Even though the attributes that are of decisive importance for the conformation of an $\mathrm{HCN}$ and the coordination of health care are accepted and acknowledged, we have not observed any studies which have considered these elements for a more pragmatic appraisal of PHC and not even that they have analysed the indicators of morbidity from $\mathrm{TB}$, from this perspective.

As the territorial areas should be the unit of intervention of PHC and the structure of an $\mathrm{HCN}$ should be organized considering the local and regional conditions of these areas, as also the respective population $[9,10,12]$, it is important to invest in new approaches that manage to bring the unit of space, also as a study object.

Even though the Geographical Information System (GIS) has not been widely used for the assessment of the health systems, this is a very interesting resource and could truthfully represent the social reality of the territories, in their interface with health service systems [14]. A systematic review revealed that GIS is a potentially powerful assessment tool for the assessment of the quality of PHC and can help in describing and explaining disparities in access and health outcomes [15].

Considering that the configuration of a health system in an $\mathrm{HCN}$ is an essential condition for the truthfulness and ability to solve problems, of the health services, and thus for the control of TB in Brazil, and also the fact 
that there are decisive or strategic characteristics for effective coordination by $\mathrm{PHC}$, we propose to investigate the issue of where, and in which attributes, the PHC has made most progress in terms of coordination of the $\mathrm{HCN}$ in a large Brazilian municipality, and also check to see whether there has been an increase in avoidable hospitalizations due to TB in the critical areas of PHC.

\section{Methods}

\section{Study design}

This is an ecological and exploratory study [16] that has considered the territorial areas gathered with the PHC as a unit of analysis.

\section{Scenery}

The study took place in the city of Ribeirão Preto, State of São Paulo, Brazil, in an area of some $650 \mathrm{~km}^{2}$ and an estimated population of 658,059 inhabitants, with about $99.7 \%$ of this population residing in urban areas [17].

It is a city of high demographic density, and is included in the group of cities that does not present favourable social indicators, instead of showing high degree of wealth [18]. Regarding the epidemiological indicators of TB, it is stressed that Ribeirão Preto is on the list of priority municipalities for the control of this disease, in 2013 reaching an incidence of 28.2 cases per 100,000 people and also a percentage of cure equal to $77.8 \%$ [19].

Regarding the geo-politico-administrative organization of the HCN, the municipality is divided into five Health Districts (North, South, Central, East and West), with differences regarding the population living in each region, ranging from 92,568 people in the South District to 173,908 people in the East District. PHC is distributed among 46 territorial areas, of which 16 (34.7\%) have Family Health Teams, these teams comprising, at the very least, one general practitioner (GP) or Family doctor, a generalist nurse, a nursing assistant or technician, and community health agents [20]. In 2013, the populational coverage provided by the PHC teams was $51.0 \%$ and the proportion of Hospitalizations for Conditions Sensitive to Primary Care (ICSAP) was 18.9 \% [19].

\section{Sources of data}

Primary and secondary data was used to respond to the goals of the study. The primary data was obtained between January and December 2014 through interviews with the health professionals, making use of a special instrument drawn up by Mendes [21] and validated by researchers from the College of Nursing at Ribeirão Preto, part of the University of São Paulo [22].

In this study, the Hospital Information System (known as $\mathrm{SIH}$, the abbreviation in Portuguese), a system that records all cases of avoidable hospitalizations resulting from tuberculosis, is also used as a source of data.

\section{Population and sample}

In the first phase of the study, the population was taken as the 1334 health professionals, of University and high school level, who work in the PHC of the municipality. A minimum non-proportional and stratified random sample was also established, as a result of heterogeneity in the number of workers, considering the different Health Districts [23], considering a level of confidence of $95 \%$, with a tolerable sampling error of $5 \%$, statistical power of the test equal to $80 \%$, and a proportion (p) of $50 \%$ of professionals who coordinate health care at the HCNs; thus a minimum sample of seven people was defined for each of the 46 units of PHC in the municipality of Ribeirão Preto.

Regarding secondary data, there was a study of avoidable cases of admittance to hospital of patients with TB, referring to codes A15.0 to A17.9 on the International Classification of Diseases (ICD-10), representing the clinical manifestations of TB that are sensitive to Primary Health Care, according to the laws and normative rulings of Brazil [24] between 2006 and 2012.

\section{Instruments of measurement}

In this study, a questionnaire was used to assess Networks, consisting of 78 structured questions, using a five-point Likert scale, with responses of total disagreement (1); disagreement (2); neutral opinion (3), agreement (4) and total agreement (5), and also comprising five different attributes according to Table 1.

To characterize the health professional of the study, the variables considered were professional category, sex, age, time with the institution, and work schedule. As for TB available hospitalizations, the authors considered two variables: sex and age.

For this study, there was also consideration of the cartographic base of the PHC territorial areas, made available by the Company for the Economic Development of Ribeirão Preto (CODERP) and also the base of the digital road system, StreetBase Basic ${ }^{\circ}$ acquired from the company Imagem ${ }^{\circ}$.

\section{Analysis of data}

The primary research data was entered in duplicate and in an independent manner. In the beginning, descriptive statistics was applied using the software Statistica version 7.9, with a counting of the categorical variables (sex) and also the calculation of measurements of central tendency (mean and median) for continuous variables, which are age of the professional and of the case of hospitalization, time of professional with the institution; these variables were categorized based on the median. 
Table 1 Attributes and their items to assess progress of the PHC in terms of coordination of the HCN

\begin{tabular}{|c|c|c|c|c|}
\hline $\begin{array}{l}\text { Attribute of the } \\
\text { instrument for data } \\
\text { collection }\end{array}$ & Essence of content of items** & $\begin{array}{l}\text { Number of items of the } \\
\text { instrument, by dimension }\end{array}$ & $\begin{array}{l}\text { Nature of } \\
\text { the Variable }\end{array}$ & Scale \\
\hline Population & $\begin{array}{l}\text { Lives in single sanitary territories, with social } \\
\text { organization into families, and being recorded } \\
\text { and filed into subpopulations based on social } \\
\text { and sanitary risks. }\end{array}$ & 14 & Politomic & $\begin{array}{l}\text { Likert - Five-point rating scale } \\
\text { (from total disagreement to total } \\
\text { agreement). }\end{array}$ \\
\hline Primary Health Care & $\begin{array}{l}\text { RAS Communications Centre, through which } \\
\text { all the services offered by the network } \\
\text { communicate with each other }\end{array}$ & 19 & & \\
\hline Support System & $\begin{array}{l}\text { These are the institutional venues where services } \\
\text { common to all health care points are offered, in } \\
\text { the fields of diagnostic support and therapy, } \\
\text { pharmaceutical assistance and also the health } \\
\text { information systems. }\end{array}$ & 15 & & \\
\hline Logistic System & $\begin{array}{l}\text { These are technological solutions, anchored to } \\
\text { information Technologies, which ensure that } \\
\text { there is an organization of regulation of access, } \\
\text { throughout the points of health care and support } \\
\text { systems, in the networks. }\end{array}$ & 16 & & \\
\hline Governance System & $\begin{array}{l}\text { This is the organizational or pluriinstitutional } \\
\text { arrangement that allows the management of all } \\
\text { the components of the RAS, so as to generate a } \\
\text { co-operative excess between the social players in } \\
\text { a situation that could increase the interdependence } \\
\text { between them and lead to good health and } \\
\text { economic results for the adstricted population. }\end{array}$ & 14 & & \\
\hline
\end{tabular}

Note: (**Adapted from Rodrigues et al. [25])

To assess progress of the PHC in terms of coordination of the HCN, the authors considered the data obtained through application of the tool to the health professionals. During the process of analysis, the scores (Sc) were duly calculated, by attributed score or globality, using the following formula:

$$
S c=\frac{\sum i t}{N p} \times 200
$$

Where $\sum i t$ is the sum of responses to all Likert items for each attribute or all attributes (globality) and $\mathrm{N}$ is number of health professionals $(\mathrm{Np})$ from the PHC facility who participated of the study. For each PHC facility, a score was calculated and health unit was classified in relation to the quartiles, adopting the criteria: Between 0 and $25 \%$, unsatisfactory condition of the PHC in that attribute or with the attribute considered globally in coordination of the HCNs; 25.01 to $50 \%$, fairly good condition of the PHC; 50.01 to $75 \%$, good condition of the PHC; and 75.01 to $100 \%$, excellent condition of the PHC [26].

Next, coropletic maps were constructed, with the classification of globality and also by attributes, making use of the ArcGIS software, version 10.2. In possession of the maps, the next step was the geocoding of the avoidable hospitalizations as a result of TB. At this stage, it was necessary to standardise the addresses according to the digital road system base in a 'shapefile' file, with a SIRGAS 2000 UTM Zone 23S projection, then proceeding with the process of association of table data to a map which is incorporated into a SIG environment with the use of the TerraView software, version 4.2.2.

As not all the addresses have been found on the cartographic database, we made use of the Batch Geocode and Findlatitudeandlongitude packages, to help with the process of geocodification [27]. Later, there was the calculation of the raw annual rate of admittances to hospital for each territory of PHC, considering the numerator as being the total number of hospitalizations which occurred in the 7 years $(Y i)$ and the denominator being the population residing in the territory $(P i)$ in the year 2012 . The rates thus obtained were multiplied by 100000 and the results thus obtained were then multiplied by a factor of $1 / 7$, to obtain the mean annual rate of hospitalization by PHC territory, based on the formula [28]:

$$
T b_{i}=\frac{Y_{i}}{P_{i}} \times \frac{1}{7} \times 100,000
$$

After obtaining the annual rate, these were subjected to the mitigation process caused by the use of the empirical Bayesian model, with the aim of reducing the socalled oscillations of small numbers and also the events of interest based on the sub-register [29]. As a result of 
the application of the method, we have obtained a weighted average between the raw rates of the PHC territories and the rate of the region of the closest neighbours, taken as a reference. For these analyses we used the Terraview software, version 4.2.2. Next, there was generation of the map with the distribution of the local empirical Bayesian rates, grouped into quintiles using the ArcGIS software, version 10.2.

Multiple linear regression was then performed, using the method of least squares and also the strategy known as Stepwise Forward Selection, using the same attributes as for the Networks (Table 1) as independent variables and the annual gross rate of avoidable hospitalizations for TB as dependent, backed up by the criterion of the choice of the best explicative model, based on the highest value of adjusted R2 [30].

\section{Ethical considerations}

The study was approved by the Research Ethics Committee of the School of Nursing of Ribeirão Preto, of the University of São Paulo (EERP/USP), in compliance with Ruling No. 466/2012 of the National Health Council, and also of the Regulating Standards and Guidelines for research involving human subjects, under protocol number 20036113.9.000.5393.

\section{Results}

Table 2 shows the characteristics of 355 health professionals who have been recruited for the study, observing that $220(81.7 \%)$ were female, 184 (51.8 \%) were under 46 years of age, and there was a prevalence of workers with a high-school education, with 89 (25.1\%) being Nursing Assistants or Technicians and 83 \% (23.4 \%) being Community Health Agents (CHAs).

We also noticed that 99 (27.9\%) of the workers have been associated to PHC services for less than 5 years, while $69(19.4 \%)$ are associated for over 20 years.

We identified 169 cases of avoidable hospitalizations through TB, which works out at an average rate of 26.2 cases per 100,000 people. We could also observe that most hospitalizations were among males $(n=134$, $79.3 \%$ ) with a mean and median age of 48 years, a minimum age of 6 and a maximum of 98 years, with a standard deviation (SD) of 16.2 years.

Figure 1 brings the classification of the PHC units, observing the fact that five had reasonable conditions for the coordination of health care and the others showed good conditions.

Figure 2 shows the classification of the territories of the PHC units, according to the $\mathrm{HCN}$ attributes. We see that none of them has been considered unsatisfactory, while only one was excellent, in the Population attribute. We also see some diversity with regard to the
Table 2 Social and demographic characteristics of the health professionals working in Primary Health Care, Ribeirão Preto, São Paulo, Brazil (2014)

\begin{tabular}{lll}
\hline Variables & $\mathrm{n}(355)$ & $\%$ \\
\hline Sex & & \\
Male & 65 & 18.3 \\
Female & 290 & 81.7 \\
Age & & \\
$\leq 46$ years & 184 & 51.8 \\
$>46$ years & 171 & 48.2 \\
Professional Category & & \\
Nursing Assistant and Technician & 89 & 25.1 \\
CHA & 83 & 23.4 \\
Doctor & 49 & 13.8 \\
Nurse & 45 & 12.7 \\
Other Technicians & 44 & 12.4 \\
Dentist & 29 & 8.1 \\
Other University-level professional people & 16 & 4.5 \\
Years in the position & & \\
$\leq 5$ & 99 & 27.9 \\
$5-10$ & 90 & 25.3 \\
$10.1-15$ & 58 & 16.3 \\
$15.1-20$ & 39 & 11.1 \\
$>20$ & 69 & 19.4 \\
\hline
\end{tabular}

performance of the health units, seeing that they are classified either as reasonable or good.

In the North District, a health unit got reasonable values in four of the five attributes assessed, except in Support Systems, which were considered good at the unit. We can also see that, as a rule, the PHC territories showed a good result in most attributes, such as Population $(n=37 ; 80.4 \%)$, Primary Health Care model $(n=43$; $93.5 \%)$, Support System $(n=45 ; 97.8 \%)$; however, in relation to the Logistic System $(n=32 ; 76 \%)$ and Governance System, a smaller number of territories showed this classification ( $n=31 ; 67.3 \%)$.

Figure 3 shows the maps constructed by considering local raw and Bayesian rates for avoidable hospitalizations, and here we can see a slight mitigation on the second map; however, most of the territories have not shown significant changes when it comes to the annual rates.

The darker areas have shown themselves to be more critical, in relation to the occurrence of hospitalizations and, after the due mitigations, these rates varied between 42.20 to 57.66 cases per 100,000 people, with most of the areas of the East Zone being in this condition. We have also seen some critical areas in other Health Districts, but to a lesser degree. 


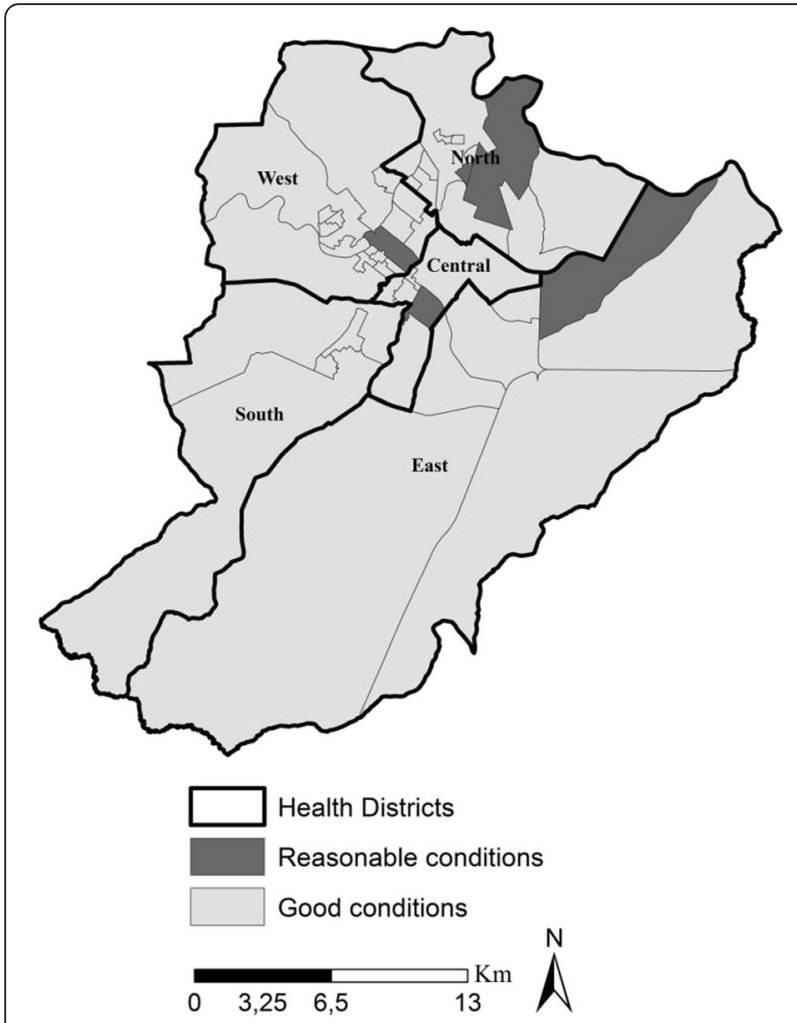

Fig. 1 Classification of Primary Health Care, according to the capacity of coordination, Ribeirão Preto, São Paulo, Brazil (2014)
In a comparative analysis between Figs. 2 and 3b, we see that in the case of the Population attribute, the territories of the PHC units considered as being of regular condition had rates ranging from 34.96 to 36.90 cases per 100,000 inhabitants. The Logistic System attribute had the largest number of areas considered as being of regular condition, and their rates ranged between all the values obtained (32.89 to 36.90 ).

In relation to the Support System, many of the territorial areas in reasonable condition posted rates ranging from 32.89 to 34.95 cases per 100,000 people. The Governance System attribute also showed a considerable number of areas with reasonable conditions, but the rates here ranged from 32.89 to 57.66 cases per 100,000 inhabitants.

Using the model of multiple linear-regression, we saw no evidence of a statistically significant connection between the Health Care Networks and avoidable hospitalizations for TB ( $22=-0.003118 ; p=0.4465)$.

\section{Discussion}

Main findings of this study

The purpose of this study was to investigate which territorial areas and which attributes have presented a greater advancement of $\mathrm{PHC}$, in terms of coordination of the HCNs, and also to check if, in critical areas of $\mathrm{PHC}$ with regard to coordination, there have been more cases of TB avoidable hospitalizations.

The results show that, as a rule, the PHC has shown good conditions for the coordination of the $\mathrm{HCNs}$, but

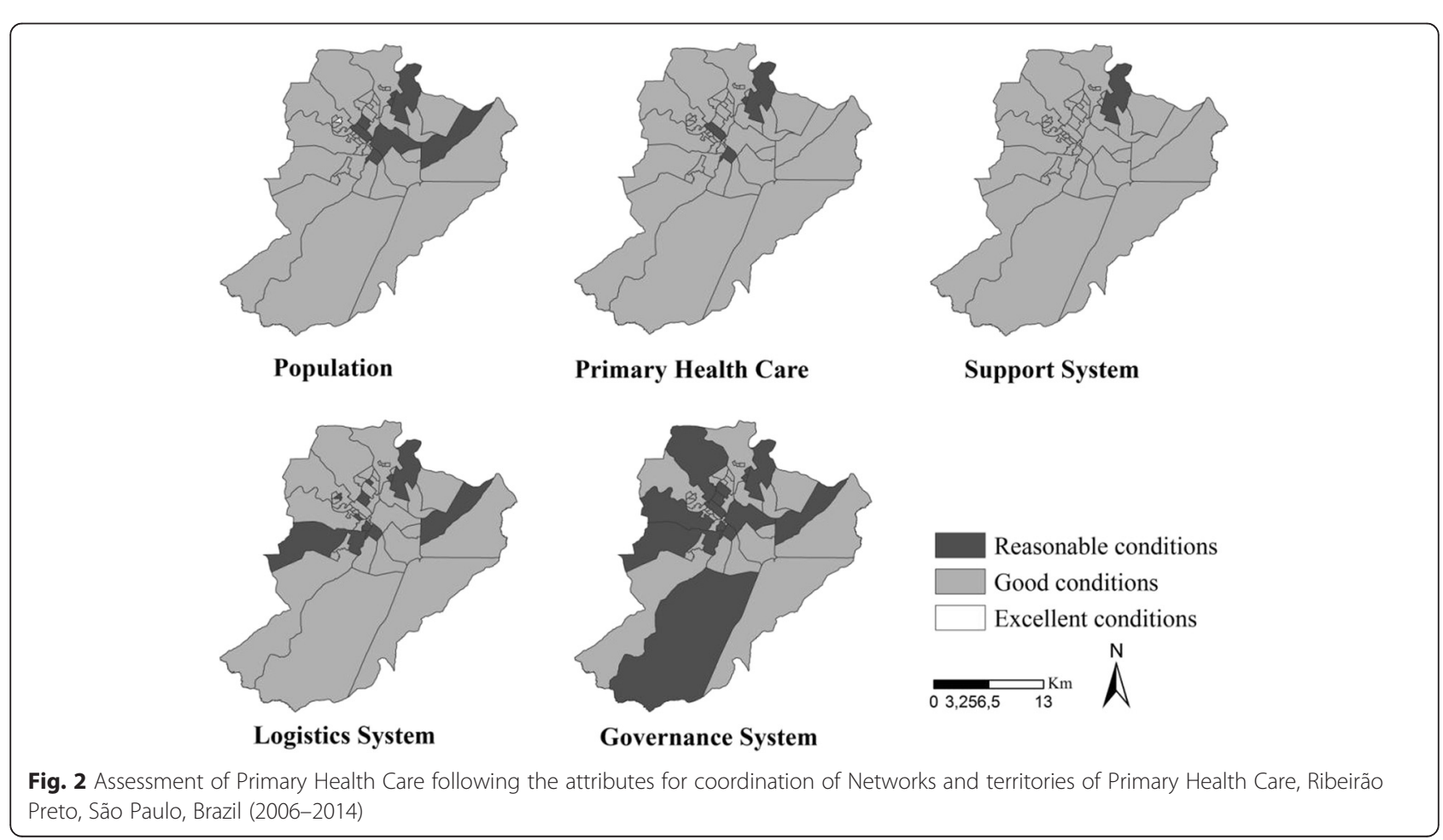



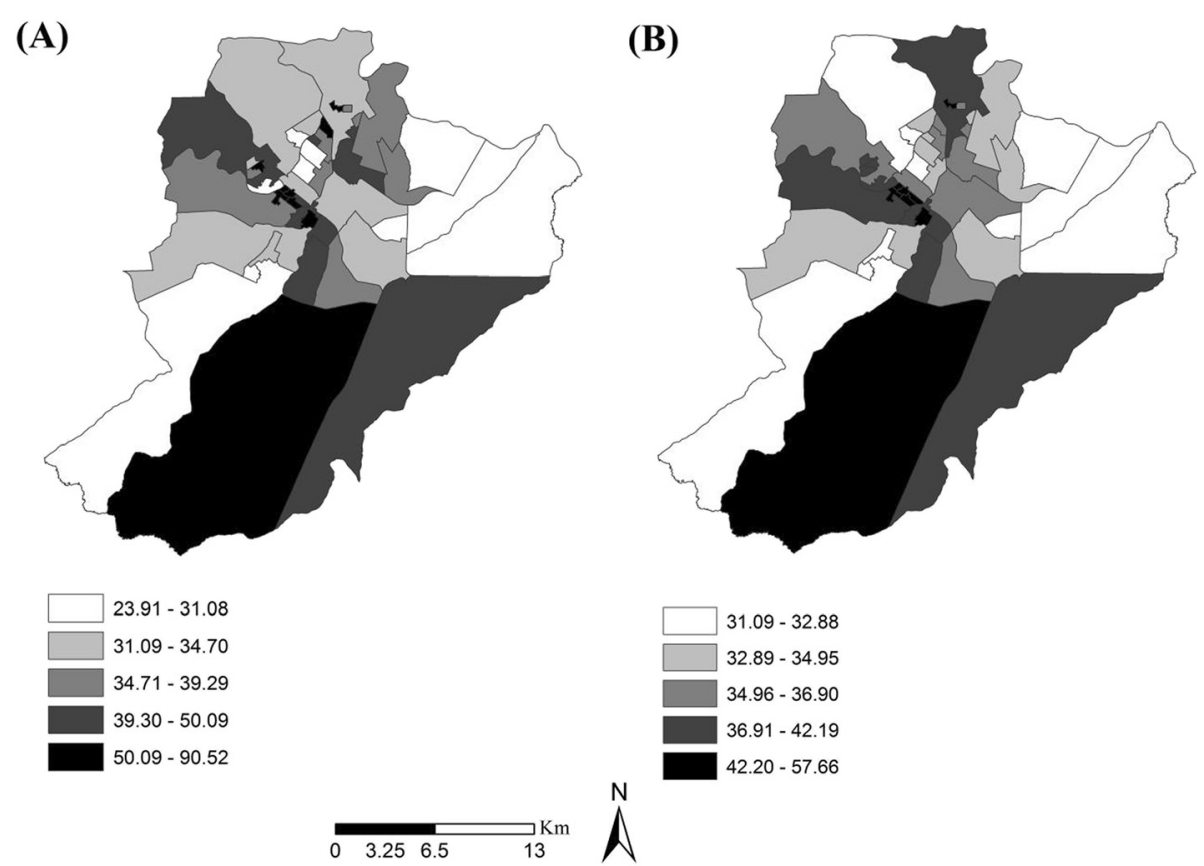

Fig. 3 Coropletic map of raw rates (a) and Bayesian rates (b) for TB avoidable hospitalizations, Ribeirão Preto, São Paulo, Brazil (2006-2012)

has shown itself to be weak in relation to the Logistic Systems and Governance Systems attributes.

Regarding the rates of avoidable hospitalizations, in the municipality studied we observed annual rate of 26.2 cases per 100,000 people, a rate which is well above the national mean of 7.2 cases of hospitalizations per 100,000 people, and also above the rate of the State of São Paulo, which came to 4.2 cases per 100.000 inhabitants [31].

In a comparative analysis, comparing results with those from other countries like China, also on the list of the 22 countries that account for $80 \%$ of TB cases in the world, we see that the rates of avoidable hospitalizations are less, as in that country, according to a study, practically $91 \%$ of all TB cases diagnosed had prior hospitalization [32], which has also been made evident in other countries in Asia and Africa [33]. One issue that must be made evident is that many countries have found difficulties to overcome the hospital-centred model, moving to that of Primary Health Care, ordering the Networks [34].

Studies show that when the PHC is of high quality and has the capacity to co-ordinate the Health Care Networks (HCNs) [8]. It also has the capacity to significantly reduce avoidable hospitalizations [35, 36]; however, the study showed no evidence of this relationship.

In addition, we can see important variations in PHC, when it comes to its capacity of co-ordination, which can be justified by the diversity in relation to the model of attention, seeing that some units have made more progress regarding the attributes of coordination, and others less. It is also important to highlight that the process for the establishment of an attention model does not follow linear logic and is, first and foremost, a vector resulting from external forces (for example, quality of human resources) of the health policies inherent to the system itself, such as adjacent social values, community movements, material and non-material resources, and the education of workers and of the community [37]. Therefore, these are forces that partly overlap and result in the performance of the unit, which could explain the differences which have been found in the results of the study.

Another point to be considered is the lack of proportion in the size of the PHC territorial units, with some being very small and some relatively larger, which could also have had an effect on the performance of health units. The larger areas are entirely made up of traditional Basic Health Units (UBS), in which the logic for offer of actions is based on the programmed agenda and spontaneous demand of the users, different from the Family Health Strategies (FHSs), essentially based on the clustering of the clients, which is an important tool when one seeks to establish the coordination of a system [38].

\section{What is already known about this topic}

It must also be mentioned that Brazil has amassed, in its track record, some experiences with the traditional model, and one of the challenges that now looms is that of the conversion of this model to FHS [39, 40]. One must also mention the nationwide effort, through 
inductive and encouraging policies, to obtain the implementation of FHS as an alternative care model which is more focused on the management of the disease; however, some impasses are still significant, such as the settlement of professionals, the demand for establishment of career, post and salary plans, and also the Law of Tax Responsibility, making the management of municipalities more difficult, in the attainment of this goal [41].

The East District, which includes the more socially affluent regions of the municipality, was the sector which showed the highest number of hospitalizations, and one of the reasons considered to explain this fact was related to the peripheral areas wrapped around the condominiums of the more wealthy segments of the population. Here we stress that, in these areas, there is a low percentage of people who are dependent on the Unified Health System (SUS), and this may somehow interfere in accessibility of health services [42]. In addition, this district has good coordination conditions for most attributes and globality of PHC.

We can also see that the North District has shown some critical areas when it comes to avoidable admittances to hospital, but, in a situation different from that in the East District, its territories have a reasonable condition in relation to the HCNs. This District has the lowest Municipal Human Development Index (MHDI) when compared to the others, and also has a higher demographic density per household, the largest number of subnormal clusters and the highest percentage of people who are exclusive users of the SUS [42]. One explanation of the result found refers to the non-availability of tools within the scope of PHC to cope with social problems that recur in the territory, such as violence, drugs, extreme poverty, educational problems, unhealthy living conditions, and unemployment, among others [43].

Similarly, in Latin America, another challenge that looms is that of overcoming the conception of $\mathrm{PCH}$ as a level within a health system, or even a focus on the less affluent segments of the population, with improvised funding and low professional qualification. This context is widely different from that of most European countries, which have implemented PHC as a coordination axis for a system, and universal coverage for all segments of the population, regardless of economic or social status $[44,45]$. This means that the main challenge for the $21^{\text {st }}$ Century is the very institution of PHC, in an expanded and wide-scope perception, as recommended by PAHO $[46,47]$.

It shall also be mentioned that the solution for the crisis of the health systems throughout the world is now betting on a new logic, that of organising them under the control of PHC [7], which PAHO sees as an innovative development in Latin America [46]. In the opinion of Mendes [21], only PHC has the capacity of coordinating the system and catering to $85 \%$ of health needs, with this institution also having the responsibility of regulating users through the Health System and, for this, there is a need for instruments and also for the innovation of the processes $[48,49]$.

\section{What this study adds}

Several authors $[10,46,50-52]$ consider the weight that the chronic conditions have upon global health, and diseases such as TB cannot be countered with efficiency, effectiveness and solution ability through Health Systems that are organized in a fragmented manner, as not only does this produce diseases resulting therefrom, but this is not cost-effective and causes a lot of human suffering.

Based on this context, the study can help towards making a situational diagnosis of PHC and also show relevant aspects for the establishment of a system in HCNs. The municipality did not achieve a classification of excellent in relation to the integration of its system, but may take a step in this direction, provided there is a review of some aspects such as the Logistic System itself, through the implementation of electronic files and computerized systems which allow the PHC to coordinate the users through the health system. It is important to introduce a unique and integrated communication system that allows fluid connection between different points of attention, or even with the introduction of systematic devices for effective communication between the systems that are already in existence.

Another possibility is an investment in the transport system, thereby allowing the user to move between different points of attention. It is therefore seen that the responsibility for health does not rest only with the user, but is shared with $\mathrm{PHC}$, as a party that is co-responsible for the health of the territory, thereby providing all the means and resources so that this user may access the different health services within a HCN, from the perspective of integrality of actions.

The Logistic Systems, in turn, are presented by PAHO [46] as being technological solutions for the transformation of local health systems into HCNs, but these have strong influence of the current health care model, considering that if the work logic in a certain unit is not open to innovations, no matter how many tools are introduced, then it is highly unlikely that they shall have any impact on the supply and the production of their actions.

The study by Onocko-Campos [53] which aimed at appraising the innovative strategies of $\mathrm{PHC}$, brings as new challenges the implementation of new production modes in the health area and also the investment in technologies that allow the coordination and monitoring of the user with chronic illnesses, during the course of 
time. Nodaria et al. [48] also presents, in their study, the innovation of $\mathrm{PHC}$, bringing interesting findings and results, on introduction of a registration and information system, such as better acceptance, speed of service, and user satisfaction.

The introduction of a Logistic System is part of a rational and honest organization of flows and counterflows of information, products and people at the HCNs, thereby favouring a system which is effective with regard to reference and counterreference throughout the health care points and Support Systems [10, 46, 51, 52, 54-56].

Governance is another issue that has been made evident in the study, with it being of great value to set a mission and also common goals between the different players and managers who are part of the system, so as to establish a cooperative network and also to complement actions, seeking integrality and equity in the supply of health services. Another important investment when the consolidation of a $\mathrm{HCN}$ is sought is the reinforcement of the process of regionalization with solidarity, between the Health Districts and even between territorial bases, as the idea of working as a Network makes it somewhat possible to have homogeneity regarding the performance of the units, as these are then developed almost in an independent and cooperative way [10].

In addition, the analysis by attributes of the instrument has allowed the identification of the poorest-performing territorial areas, when it comes to coordination. Albeit in lesser quantity, some areas have had their units joined together under regular conditions in the attributes of Population, PHC and Support Systems; Moreover, in these areas there were distinct situations regarding hospitalizations for TB that were considered avoidable, meaning that it is not possible to establish any kind of relationship between the events.

One possible explanation for the result is due to the centrality of the attention for TB in reference outpatient departments, and also the non-sharing of responsibilities between the reference units and PHC [56-60], which ends up interfering with the results of the study. However, it is important to mention that it is the responsibility of PHC to carry out actions for promotion of health and prevention in the health sector, and within the perspective of HCNs, it would be the responsibility of the $\mathrm{PHC}$ to coordinate these patients, this being a point that needs to be reviewed by the management team and in which further studies are necessary.

In relation to the analysis of the cases of $\mathrm{TB}$ avoidable hospitalizations, there was the mention of some advantages of application of local empirical Bayesian rates with regard to the raw rates. The Bayesian rates showed lesser variability and a greater adjustment to the real risk of occurrence of the event in each area of the region under study. For those areas where the raw rate would show significant variability, the local empirical Bayesian method has allowed a special effect on the estimates, bringing them closer to a local mean, which generated certain mildness in the thematic map.

Here, it is worth adding that no other study has appraised the $\mathrm{HCNs}$ coordinated by the $\mathrm{PHC}$ considering the technologies for spatial analysis, possibly with this being a relatively new issue in Brazil. This technology has showed itself to be really interesting in that it maps a social reality of the PHC units and also shows the territorial areas that are most critical. From the standpoint of management, these areas could be prioritized in terms of sanitary investment and planning; within a proposal of establishment of a Network, this study points to areas that are of priority importance for the project.

\section{Limitation of the study}

Due to the ecological approach, there are some limitations inherent to this kind of study, such as ecologic fallacy or bias, which renders it impossible to transport the findings to the individual reality [61].

Despite a probabilistic design of the sample, there are some variables which do indeed interfere with the generalization of the sample for the population of processional people, such as the turnover of professionals, holiday entitlements, sick leave, acceptance of the study, and others. In one health unit, there was a rejection of about $30 \%$ of the team of professionals, especially within the medical category. One strategy that was considered by the authors was that of an articulation with the managers of the services and the coordinators of the Health Districts, which made interaction with the professional staff easier.

To this, we also add, as an additional limitation, the use of secondary data, such as subnotifications and incomplete information which [62], as a result, may not be representative of the real incidence of available hospitalizations within the municipality studied. In addition, it was noticed that, in critical areas of $\mathrm{PCH}$ related to the performance of coordination and the occurrence of avoidable hospitalizations, there was no evidence that would confirm this relationship, meaning that there could be other variables to explain these hospitalizations and which interfere with accessibility; elements such as poverty, social exclusion, malnutrition, and other documents determining access [63]. Furthermore, in the study there was the use of one single instrument using closed questions, to assess different models of PHC, which are immersed in singularities and subjectivities of the professional people, and this, to a certain extent, could have brought a certain bias to the study. For any future investigations, it would be an interesting proposition 
to carry out qualitative studies to identify possible explanations for avoidable hospitalizations for TB, as this could not be explained with a quantitative diagram.

\section{Conclusion}

The study showed the problem of avoidable hospitalizations for TB in an endemic city in Brazil, noting a random distribution of hospitalizations regardless of the quality of the PHV in the co-ordination of Health Care Networks (HCNs).

In terms of the quality of PHC, it was observed that, as a rule, most of the units were within satisfactory standards; however, two of the attributes here appraised were considered as only regular, namely Logistics Systems and the System of Governance. In relation to the Logistics Systems, we were able to observe the lack of an effective system for reference and counter-reference of people and information, throughout the health services offered within the Health Care Networks (HCNs). In relation to the Governance System, the lack of co-operative actions between the different health services and also the lack of definition of a single mission and target, related to the supply of, and actions within, health services.

Through GIS technology, it has been possible to identify the PHC areas that are most deficient with regard to these aspects, thereby contributing with local management in the mapping of critical areas and/or with a more fragile PHC, collaborating towards planning and promotion in the health sector which is better guided, so as to make progress in the improvement of quality and the strengthening of a health service offered by PHC.

\section{Competing interests}

The authors declare that they have no competing interests.

\section{Authors' contributions}

MPP, MMT, MY, LBBR participated in the conception of the project, as well as the analysis and interpretation of the data and the wording of the article; MCCG, MSN, FCN participated in the analysis and interpretation of the data and also a relevant critical review of the intellectual content. LHA, ACVR, TZB, JAC, ICP, PFP, SACU, IF, LMVL participated in the relevant critical review of the intellectual content. RAA participated in the conception of the project, data analysis and interpretation, the general preparation of the article, and also a relevant critical review of the intellectual content. All the authors have read and approved the final manuscript.

\section{Acknowledgements}

We are grateful to the Municipal Secretariat for Health, for the partnership and support they have provided in the materialization of the study. We also thank the coordinators of the Health Districts, for the articulation with the managers of the Units and also as they have made it possible for us to participate in the Ordinary General Meeting for the presentation of the study. We thank the managers of the Health Units who have so kindly opened the doors of their Units to our team, also encouraging the participation of their employees. We thank the health workers for having agreed to participate in the study, essentially as they have believed in the potential of Primary Health Care for a change in model. Last but not least, to the team from the Reference Hospital for making available the secondary data. The Foundation of Support for Research of the State of São Paulo (Fundação de Amparo e Apoio à Pesquisa do Estado de São Paulo - FAPESP) (Processes No. 2012/51235-5 and No. 2013/22486-2).

\section{Author details}

Maternal-Infant and Public Health Nursing Department, College of Nursing of Ribeirão Preto, University of São Paulo, Av dos Bandeirantes 3900, 14040-902 Ribeirão Preto, São Paulo, Brazil. ${ }^{2}$ Institute for Health Sciences, Federal University of Mato Grosso, Av Alexandre Ferronato 1200, Reserve 35, 78550-000 Sinop, Mato Grosso, Brazil. ${ }^{3}$ Centre of Social Sciences, Health and Technology of the Federal University of Maranhão (UFMA), Rua Turqueza, 65900-410 Imperatriz, Maranhão, Brazil. ${ }^{4}$ Department of Epidemiology, Faculty of Public Health, University of São Paulo, Avenida Dr. Arnaldo, 715, 01246-904 São Paulo, São Paulo, Brazil. ${ }^{5}$ Department of Group Health, Federal University of Rio Grande do Norte, Avenida Senador Salgado Filho, 3000Rio Grande do Norte 59078-970 Natal, Brazil. ${ }^{6}$ WHO Collaborating Centre for Health Workforce Policy and Planning, International Public Health and Biostatistics, Global Health and Tropical Medicine, Instituto de Higiene e Medicina Tropical, Universidade Nova de Lisboa, Rua Junqueira 100, Lisbon P-1349-008, Portugal. 'International Public Health and Biostatistics, Global Health and Tropical Medicine, Instituto de Higiene e Medicina Tropical, Universidade Nova de Lisboa, Rua Junqueira 100, Lisbon P-1349-008, Portugal.

Received: 3 July 2015 Accepted: 11 February 2016

Published online: 01 March 2016

\section{References}

1. WHO. World Health Organization. Global Tuberculosis Report 2014: WHO report 2014. Geneva: WHO; 2014.

2. Brasil. Ministério da Saúde. Manual de Recomendações para o controle da tuberculose no Brasil. Departamento de Vigilância Epidemiológica. Brasília: Ministério da Saúde; 2011. 284p.

3. Oliveira GP, Torrens AW, Bartholomay P, Barreira D. Tuberculosis in Brazil: last ten years analysis - 2001-2010. Braz J Infect Dis. 2013;17(2):218-33.

4. Oliveira NF, Gonçalves MJF. Fatores sociais e ambientais associados à hospitalização de pacientes com tuberculose. Rev. Latino-Am. Enfermagem. 2013;21(2):507-14.

5. Perrechi MCT, Ribeiro AS. Desfechos de tratamento de tuberculose em pacientes hospitalizados e não hospitalizados no município de São Paulo. J Bras Pneumologia. 2011;37(6):783-90.

6. Arcêncio RA, Oliveira MF, Villa TCS. Internações por tuberculose pulmonar no Estado de São Paulo no ano de 2004. Ciênc. saúde coletiva. 2007;12(2):409-17.

7. The lancet. Making primary care people-centred: a 21st century blueprint. Lancet. 2014;384:281. http://www.thelancet.com/pdfs/journals/lancet/ PIIS01406736(14)61243-5.pdf. Accessed 06 Mar 2015.

8. PAHO. Pan American Health Organization. Integrated Health Service Delivery Networks: concepts, policy options and a road map for implementation in the Americas. Washington, D.C: PAHO; 2011.

9. OPAS. Organização Pan-americana da Saúde. Inovando o papel da atenção primária nas redes de atenção à saúde. Série técnica para os gestores do SUS sobre redes integradas de atenção à saúde baseadas na APS. Brasília: OPAS; 2011

10. Mendes EV. As Redes de Atenção à Saúde. Brasília: OPAS; 2011.

11. Malta DC, Duarte EC, Almeida MF, Dias MAS, Morais Neto OL, Moura L, et al. Lista de causas de mortes evitáveis por intervençōes do Sistema Único de Saúde do Brasil. Epidemiol Serv Saude. 2007;16(4):233-44.

12. OPAS. Organização Pan-americana da Saúde. La Renovación de la Atención Primaria de Salud en las Américas. Documento de Posición de La Organización Panamericana de La Salud/Organización Mundial de la Salud (OPS/OMS). Washington, D.C: OPAS; 2007.

13. Montenegro H, Holder R, Ramagem C, Urrutia S, Fabrega R, Tasca R, et al. Combating health care fragmentation through integrated health services delivery networks in the Americans: Lessons Learned. Int J Integr Care. 2011; 9(5):e100.

14. Guimarães RB, Ribeiro H. O tratamento cartográfico da informação em saúde do trabalhador. Rev. bras. epidemiol. 2010;13(4):577-586.

15. Graves BA. Integrative Literature Review: A Review of Literature Related to Geographical Information Systems, Healthcare Access, and Health Outcomes. Perspect Health Inf Manag. 2008;5(11):1-7.

16. Medronho RA, Carvalho DM, Block KV, Roner LB, Werneck V, Guilherme L. Epidemiologia. São Paulo: Editora Atheneu; 2006.

17. IBGE. Instituto Brasileiro de Geografia e Estatística. Coordenação de população e indicadores sociais. http://cidades.ibge.gov.br/xtras/perfil. php?codmun=354340. Accessed 06 Mar 2015. 
18. SEADE. Fundação Sistema Estadual de Análise de Dados. Perfil Municipal. http://www.imp.seade.gov.br/frontend/\#/perfil. Accessed 23 Fev 2015.

19. Secretaria Municipal da Saúde. Prefeitura Municipal de Ribeirão Preto. Plano Municipal de Saúde 2014-2017. https://www.ribeiraopreto.sp.gov.br/ssaude/ pdf/pms-rp-2014-2017.pdf. Accessed 06 Mar 2015.

20. Brasil. Ministério da Saúde. Secretaria de Atenção à Saúde. Departamento de Atenção Básica. Política Nacional de Atenção Básica / Ministério da Saúde. Secretaria de Atenção à Saúde. Departamento de Atenção Básica. Brasília : Ministério da Saúde, 2012.

21. Mendes EV. O cuidado das condições crônicas na atenção primária à saúde: o imperativo da consolidação da estratégia da saúde da família. Brasília: Organização Pan-Americana da Saúde; 2012.

22. Rodrigues LBB, Leite AL, Yamamura M, Deon KC, Arcêncio RA. Coordenação das Redes de Atenção à Saúde pela Atenção Primária: validação semântica de um instrumento de avaliação. Cad Saúde Pública. 2014;30(7):1385-90.

23. Daniel J. Sampling Essentials: Practical Guidelines for making Sampling Choices. USA: SAGE; 2012.

24. Brasil. Ministério da Saúde. Consulta Pública N. 4, de setembro de 2007 Lista Brasileira de Internações Hospitalares por Condições Sensíveis à Atenção Básica. Brasília: Diário oficial da União; 2007. 21 set.

25. Rodrigues LBB, Santos CB, Goyatá SLT, Popolin MP, Yamamura M, et al. Assessment of the coordination of integrated health service delivery networks by the primary health care: COPAS questionnaire validation in the Brazilian context. BMC Fam Pract. 2015;16:87.

26. Pedroso B, Gutierrez GL, Duarte E, Pilatti LA, Picinin CT. Avaliação da Qualidade de vida de portadores de HIV/Aids: uma visão geral dos instrumentos WHOQOL-HIV e WHOQOL-HIV-BREF. Revista da Faculdade de Educação Física da UNICAMP. 2012;10(1):50-69.

27. Zwiefelhofer D. Batch Geocoding. http://www.findlatitudeandlongitude.com. Accessed 27 May 2015

28. Brasil. Ministério da Saúde. Índice de Desempenho do Sistema Único de Saúde. Brasília: DF, 2011c.

29. Leyland AH, Davies CA. Empirical Bayes methods for disease mapping. Stat Methods Med Res. 2005:14(1):17-34

30. Harrell F. Regression modelling strategies: with applications to linear models, logistic and ordinal regression, and survival analysis (springer series in statistics). 2015

31. San Pedro A, Oliveira RM. Tuberculose e indicadores socioeconômicos: revisão sistemática da literatura. Rev Panam Salud Pública. 2013;33(4):294-301.

32. Zou G, King R, Walley J, Yin J, Sun Q, Wei X. Barriers to hospital and tuberculosis programme colaboration in China: context matters. Global Health Action. 2015;8.

33. Chiang CY, Trébucq A, Billo N, Khortwong P, Elmoghazy E, Begum V, et al. A survey of TB services in hospitals in seven large cities in Asia and North Africa. Int J Tuberc Lung Dis. 2007;11(7):739-46.

34. WHO. World Health Organization. The World Health Report 2008 - Primary Health Care (now more than ever). Geneva, 2008.

35. Laditka JN, Laditka SB, Probst JC. More may be better: evidence of a negative relationship between physician supply and hospitalization for ambulatory care sensitive conditions. Health Serv Res. 2005;40(4):1148-66.

36. Rosano A, Abo Loha C, Falvo R, Van der Zee J, Ricciardi W, Guasticchi G, et al. The relationship between avoidable hospitalization and accessibility to primary care: a systematic review. The European J Public Health. 2012;23(3): 356-60

37. Ferreira Neto JL, Kind L, Pereira AB, Rezende MCC, Fernandes ML. Usos da noção de subjetividade no campo da Saúde Coletiva. Cad Saúde Pública. 2011;27(5):831-42.

38. Elias PE, Ferreira CW, Alves MCG, Cohn A, Kishima V, Escrivão Junior A, et al. Atenção Básica em Saúde: comparação entre PSF e UBS por estrato de exclusão social no município de São Paulo. Ciênc saúde colet. 2006;11(3): 633-41.

39. Castanheira ERL, Dalben I, Almeida MAS, Puttini RF, Patrício KP, Machado DF, et al. Avaliação da qualidade da atenção básica em 37 municípios do Centro-Oeste Paulista: características da organização da assistência. Saúde soc. 2009;18(Suppl2):84-8.

40. Crabtree BF, Nutting PA, Miller WL, McDaniel RR, Stange KC, Jaén CR, et al. Primary care practice transformation is hard work: insights from a 15-year developmental program of research. Med Care. 2011;49(Suppl):S28-35.

41. Guimarães C. Desafios da Gestão Municipal do SUS. http://www.epsjv. fiocruz.br/upload/EdicoesRevistaPoli/R33.pdf. Accessed 17 Mar 2015.
42. Secretaria Municipal da Saúde. Prefeitura Municipal de Ribeirão Preto. Fatores de risco relacionados à saúde da população residente na zona urbana de Ribeirão preto (SP) 2008-2011. https://www.ribeiraopreto.sp.gov. br/ssaude/pdf/fatores-risco.pdf. Accessed 06 Mar 2015.

43. Silveira AC, Machado CV, Matta GC. Atenção primária em saúde na agenda da Organização Pan-Americana de Saúde nos anos 2000. Trab. educ. saúde. 2015 Epub. 2014;13(1):31-44

44. Giovanella L. Atenção Primária à Saúde seletiva ou abrangente? Cad Saúde Pública. 2008;24(Suppl1):s21-23.

45. Calmbach WL, Ryan JG, Baldwin LM, Knox L. Practice-based Research Networks (PBRNs): Meeting the Challenges of the Future. Am Board Fam Med. 2012;25(5):572-6

46. OPAS. Organização Pan-americana da Saúde. Inovando o papel da Atenção Primária nas Redes de Atenção à Saúde. Brasília: Organização Pan-Americana da Saúde; 2011.

47. Mays GP, Scutchfield DF, Bhandari MW, Smith SA. The Milbank Quarterly. Understanding the Organization of Public Health Delivery Systems: An Empirical Typology. 2010;88(1):81-111.

48. Nodari $\mathrm{CH}$, Olea PM, Dorion ECH. Relação entre inovação e qualidade da orientação do serviço de saúde para Atenção Primária. Rev Adm Pública. 2013;47(5):1243-264

49. Vargas I, Mogollón-Pérez AS, De Paepe P, Silva MRF, Unger JP, Vázquez ML. Do existing mechanisms contribute to improvements in care coordination across levels of care in health services networks? Opinions of the health personnel in Colombia and Brazil. BMC Health Serv Res. 2015;15:213.

50. Castro MSM. Desigualdades sociais no uso de internações hospitalares no Brasil: o que mudou entre 1998 e 2003. Ciênc saúde coletiva. 2006;11(4): 987-98.

51. Conill EM. Ensaio histórico-conceitual sobre a Atenção Primária à Saúde: desafios para a organização de serviços básicos e da estratégia saúde da família em centros urbanos no Brasil. Cad Saúde Pública. 2008:24(supl. 1):7-16.

52. Mendes EV. Agora mais que nunca: uma revisão bibliográfica Sobre Atenção Primária à Saúde. Belo Horizonte: [s.n]; 2009.

53. Onocko-Campos RT, Campos GWS, Ferrer AL, Corrêa CRS, Madureira PR, Gama CAP et al. Avaliação de estratégias inovadoras na organização da Atenção Primária à Saúde. Rev. Saúde Pública. 2012 epub 2011; 46(1):43-50.

54. Starfield B. Atenção Primária: equilíbrio entre necessidades de saúde, serviços e tecnologia. Brasília: UNESCO, Ministério da Saúde; 2002.

55. Giovanella L, Mendonça MHM, Escorel S, Almeida PF, Andrade CLT, Senna MCM, et al. Estudos de caso sobre a implementação da Estratégia Saúde da Família em grandes centros urbanos. Relatório final. Brasília: Ministério da Saúde; 2009.

56. Andrade RLP, Scatolin BE, Wysocki AD, Beraldo AA, Monroe AA, Scatena LM, et al. Diagnóstico da tuberculose: atenção básica ou pronto atendimento? Rev Saude Publica. 2013;47(6):1149-58.

57. Hino P, Cunha TN, Villa TCS, Santos CB. Perfil dos casos novos de tuberculose notificados em Ribeirão Preto (SP) no período de 2000 a 2006. Ciênc saúde coletiva. 2011:16(supl. 1):1295-1301.

58. Oliveira MF, Arcêncio RA, Ruffino-Netto A, Scatena LM, Palha PF, Villa TCS. A porta de entrada para o diagnóstico da tuberculose no sistema de saúde de Ribeirão Preto/SP. Rev Esc Enferm USP. 2011;45(4):898-904.

59. Beraldo AA, Arakawa T, Pinto ESG, Andrade RLP, Wysocki AD, Silva Sobrinho RA, et al. Atraso na busca por serviço de saúde para o diagnóstico da tuberculose em Ribeirão Preto (SP). Ciênc saúde coletiva. 2012:17(11):3079-86.

60. Yamamura M, Santos neto M, Freitas IM, Rodrigues LBB, Popolin MP, Uchoa ACS, et al. Tuberculose e iniquidade social em saúde: uma análise ecológica utilizando técnicas estatísticas multivariadas, São Paulo, Brasil. Rev Panam Salud Públ. 2014:35(4):270-7.

61. Szklo M, Javier NF. Basic study designs in analytical epidemiology. Epidemiology: beyond the basics. Gaithersburg: Aspen Publishers Inc; 2000.

62. Coeli CM. Sistemas de Informação em Saúde e uso de dados secundários na pesquisa e avaliação em saúde. Cad Saúde Colet. 2010;18(3):335-6.

63. Lönnroth K, Migliori GB, Raviglione M. Toward tuberculosis elimination in low-incidence countries: reflections from a global consultation. Ann Intern Med. 2014;161(9):670-1. 